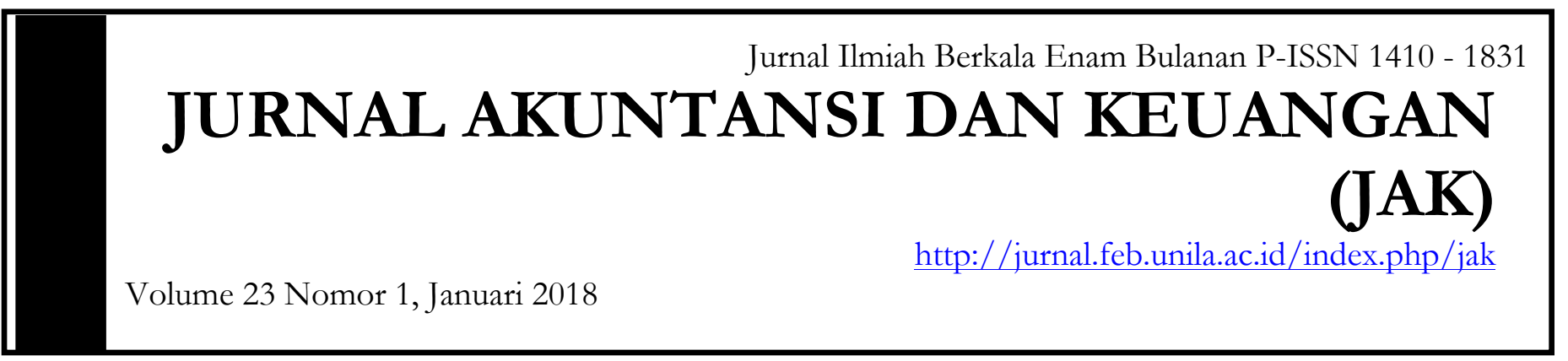

\title{
ANALISIS PENGAKUAN NILAI ASET DAN KUALITAS LAPORAN KEUANGAN SEBELUM DAN SESUDAH PENERAPAN SISTEM AKUNTANSI BERBASIS AKRUAL
}

\author{
Ika Novita ${ }^{1}$, Farichah $^{2}$, Rindu Rika Gamayuni ${ }^{3}$ \\ ${ }^{1}$ Program Studi Akuntansi FEB Universitas Lampung \\ ${ }^{2}$ Program Studi Akuntansi FEB Universitas Lampung \\ ${ }^{3}$ Program Studi Akuntansi FEB Universitas Lampung
}

\section{Informasi Naskah}

Update Naskah:

Dikumpulkan: 19 Sept

2017;

Diterima: 22 January 2018;

Terbit/Dicetak: 30 March 2018 .

\section{Keywords:}

Awareness of paying tax, knowledge and understanding of tax regulation, tax system perception, taxpayers service quality, willingness of paying tax

\begin{abstract}
This research aims to examine the affect of awareness of paying tax towards the willingness of paying tax, the affect of tax regulation knowledge towards the willingness of paying tax, perception of tax system effectiveness towards the willingness of paying tax, perceived benefits by taxpayers towards the willingness of paying tax, the quality of taxpayer services towards the willingness of paying tax. The population in this research are individual taxpayer of MSME's registered in the Pratama Kedaton and Teluk Betung Tax Office, Bandar Lampung. Sample are drawn with convenience sampling method. Data collected using questionnaire. The data uses in this research are primary data, and analysed using data quality test (validity and reliability test), classical assumption test (normality test, multicolinierity test, heteroscedasticity test), and hypothesis testing with multiple linier analysis. The result shows that there are many factors affecting the willingness of paying tax significantly are the awareness of paying tax and the quality of taxpayers services, and the tax regulation knowledge, perception of tax system effectiveness and the benefits percieved by taxpayers does not significantly affect the willingness of paying $\operatorname{tax}$.
\end{abstract}




\section{A. PENDAhuluan}

Pemerintah daerah sebagai pihak yang ditugasi menjalankan roda pemerintahan, pembangunan dan layanan sosial masyarakat, maka wajib menyampaikan laporan pertanggungjawaban keuangan daerahnya untuk dinilai apakah pemerintah daerah tersebut berhasil menjalankan tugas dengan baik atau tidak (Halim, 2011). Kewenangan dalam pengelolaan keuangan diatur dalam Undang-Undang Nomor 17 Tahun 2003 tentang Keuangan Negara. Undang-Undang tersebut mensyaratkan bentuk dan isi laporan pertanggungjawaban pelaksanaan anggaranpendapatan dan belanja negara atau anggaran pendapatan dan belanja daerahdisusun dan disajikan dengan Standar Akuntansi Pemerintahan atau SAP yang ditetapkan oleh peraturan pemerintah .

Dalam pelaksanaan otonomidaerah terkait dengan implikasi kebijakan pengelolaan barang milik daerah makapemerintah daerah memiliki peranan penting dalam mengelola asset, karena aset daerah memiliki peranan penting bagi pemerintah daerah sehingga memerlukan pengelolaan yang benar dan merupakan salah satu indikator dalam penerapan sistem akuntansi berbasis akrual, yaitu dengan penyajian laporan aset yang benar dalam Laporan Keuangan Pemerintah Daerah atau LKPD.

Perubahan konsep akuntansi dari kas menjadi akrual masih diperdebatkan karena masih banyak yang berfikir sektor publik dan swasta harus memiliki sistem yang berbeda karena memiliki karakteristik yang berbeda (Damayanti, 2013). Selain itu argumen tentang akuntansi akrual dapat memberikan akuntabilitas yang lebih baik juga mendapat tantangan dari beberapa ahli yang menyatakan bahwa tidak semua sektor publik cocok dengan kauntansi akrual dan justru akuntansi akrual sendiri yang mengaburkan informasi akuntabilitas.

Saat ini, laporan keuangan pemerintah daerah, sudah menggunakan basis akrual. Dalam perubahan sistem basis akrual ini menurut Nasi dan Steccolini (2008) bahwa salah satu pilar reformasi ditunjukkan dengan perubahan di dalam sistem akuntansi menuju adopsi laporan akrual dan sistem pengendalian manajemen. Penggunaan sistem akuntansi akrual di sektor publik merupakan reformasi dari elemen ekonomi. Ouda (2004) menyatakan tujuan utama dari reformasi sektor publik lebih responsif. Sesuai amanat dari undang-undang Nomor 17 Tahun 2003 tentang keuangan negara dan undang-undang nomor 1 tahun 2004 tentang perbendaharaan negara dan diperjelas dalam peraturan pemerintah Nomor 71 Tahun 2010 tentang Standar Akuntansi Pemerintah, maka penerapan akuntansi berbasis selambat-lambatnya tahun 2015.PP Nomor 71 Tahun 2010 mendefinisikan aset sebagai sumber daya ekonomi yang dikuasi dan atau dimiliki oleh pemerintah sebagai akibat dari peristiwa masa lalu dan dari manfaat ekonomi dan atau sosial dimasa depan dan dapat di peroleh baik pemerintah maupun masyarakat serta dapat diukur dengan satuan uang termasuk sumber daya non keuangan yang diperlukan untuk penyediaan jasa bagi masyarakat umum dan sumber-sumber daya yang dipelihara karena alasan sejarah dan budaya. Aset diklasifikasikan ke dalam aset lancar dan nonlancar. Suatu aset diklasifikasikan sebagai aset lancar jika diharapkan segera untuk dapat direalisasikan atau dimiliki untuk dipakai atau dijual dalam waktu 12 (dua belas) bulan sejak tanggal pelaporan. Aset yang tidak dapat dimasukkan dalam kriteria tersebut diklasifikasikan sebagai aset nonlancar.

Sejalan dengan Undang-Undang Nomor 17 tentang keuangan negara dan PP No. 71 Tahun 2010 tentang Standar Akuntansi Pemerintahan yang mengamanatkan implementasi akuntansi pemerintah berbasis akrual, melalui penyempurnaan proses bisnis dan sistem akuntansi berbasis kas atau kas menuju akrual yang sampai dengan tahun 2014 digunakan pemerintah dalam penyusunan LKPD, mulai tahun 2015 beralih sepenuhnya menjadi akuntansi berbasis akrual. Implementasinya diwujudkan dengan penambahan komponen laporan keuangan yaitu laporan operasional, laporan perubahan saldo anggaran lebih dan laporan perubahan ekuitas dalam unsur laporan keuangan, serta penambahan pada ciri keuangan pemerintah bagi pengendalian tentang penyusutan nilai aset sebagai sumber daya ekonomi karena digunakan dalam kegiatan operasional 
pemerintahan (PP 71 Tahun 2010 Kerangka Konseptual Paragraf 16) dan pengakuan aset (Paragraf 90) yaitu piutang atau beban dibayar dimuka diakui ketika hak klaim untuk mendapatkan arus kas masuk atau manfaat ekonomi lainnya dari entitas lain telah atau tetap masih terpenuhi, dan nilai klaim tersebut dapat diukur atau diestimasi.

Fenomena perubahan atas Sistem Akuntansi Pemerintah yang di tetapkan merupakan suatu hal yang menarik untuk dikaji lebih lanjut, karena dengan berubahnya sistem akuntansi berubah pula dalam penyusunan laporan keuangan baik dalam hal pengakuan, penilaian dan kebijakan lainnya dan akan mempengaruhi kualitas laporan keuangan itu sendiri yang tergambar dari hasil pemeriksaan oleh BPK RI. Aset tetap sebagai bagian dari aset negara merupakan faktor penting dalam pengelolaan keuangan negara. Ini tercermin dalam laporan keuangan pemerintah, dimana nilai aset tetapnya memiliki nilai paling besar dibanding komponen lain. Selain asset tetap, nilai asset yang memiliki nilai cukup besar adalah asset lancar dan juga asset lainnya. Keberadaan aset juga mempengaruhi kelancaran roda penyelenggaraan pemerintahan dan pembangunan. Sistem Pengendalian Intern atas pengelolaan aset negara harus dilakukan secara optimal untuk mencegah penyimpangan yang dapat merugikan negara.

Muhsini (2010) dalam penelitiannya menyatakan bahawa salah satu faktor yang masih harus ditingkatkan untuk meningkatkan akuntabilitas adalah tingkat adopsi terhadap suatu inovasi dalam hal ini adopsi akuntansi basis akrual dalam penyusunan laporan keuangan pemerintah dan berkesimpulan akuntansi berbasis akrual berpengaruh negatif terhadap retrurn on assets, dikarenakan adanya suatu aturan yang mengharuskan pengembalian surplus ke kas negara disamping itu pemerintah daerah hanya boleh mengajukan anggaran sebesar realisasi tahun sebelumnya. Hal ini akan mengakibatkan adanya kecenderungan dari pemerintah daerah untuk menghabiskan surplus dengan kegiatan yang sebenarnya kurang bermanfaat. Semakin banyaknya laporan keuangan yang beropini tidak wajar dan disclaimer dari tahun ke tahun menandakan bahwa akuntabilitas keuangan juga masih buruk, sehingga banyak hal yang harus dilakukan oleh pemerintah darah yang bersangkutan, diantaranya mencakup sistem pembukuan, sistem aplikasi teknologi komputer, inventarisasi aset dan utang, jadwal waktu penyusunan laporan keuangan dan pemeriksaan serta pertanggungjawaban anggaran, quality assurance atas LKPD oleh pengawas intern dan sumber daya manusia.

Berubahnya sistem akuntansi berubah pula dalam penyusunan laporan keuangan baik dalam hal pengakuan, penilaian dan kebijakan lainnya dan akan mempengaruhi kualitas laporan keuangan itu sendiri yang tergambar dari hasil pemeriksaan oleh BPK RI. Dengan demikian penulis tertarik untuk mengamati hasil perubahan sitsem akuntansi berbasis kas menjadi berbasis akrual yang telah diterapkan dan diwajibkan pemerintah untuk penyusunan LKPD. dapat lebih teratur kinerjanya. Hal tersebut diharapkan mampu mendorong efisiensi atas kegiatan-kegiatan yang dilakukan dan mendorong terwujudnya good and clean corporate governance, sehingga tujuan pembangunan untuk kemakmuran seluruh rakyat dapat dicapai. Untuk mencapai tujuan tersebut pemerintah dan seluruh pemerintah daerah harus dapat mempertahankan kualitas laporan keuangannya yang tergambar dari opini yang diberikan BPK.

\section{B. LANDASAN TEORI DAN PENGEMBANGAN HIPOTESIS \\ Teori agency}

Teori agensi menyatakan bahwa apabila terdapat pemisahan antara pemilik sebagai prinsipal dan manajer sebagai agen yang menjalankan perusahaan maka akan muncul permasalahan agensi karena masing-masing pihak tersebut akan selalu berusaha untuk memaksimalisasikan fungsi utilitasnya (Jensen dan Meckling, 1976). Terdapat cara-cara langsung yang digunakan pemegang saham untuk memonitor manajemen perusahaan sehingga membantu memecahkan konflik keagenan. Pertama, pemegang saham mempunyai hak untuk mempengaruhi cara perusahaan dijalankan melalui voting dalam rapat umum pemegang saham, hak voting pemegang saham merupakan bagian penting dari aset keuangan mereka. Kedua, pemegang saham melakukan 
resolusi dimana suatu kelompok pemegang saham secara kolektif melakukan lobby terhadap manajer berkenaan dengan isu-isu yang tidak memuaskan mereka. Pemegang saham juga mempunyai opsi divestasi, divestasi mereprestasikan suatu kegagalan dari perusahaan untuk mempertahankan investor, dimana divestasi diakibatkan oleh ketidakpuasan pemegang saham atas aktivitas manajer (Warsono, 2009).

Manajemen laba didasari oleh adanya teory agency yang menyatakan bahwa setiap individu cenderung untuk memaksimalkan utilitasnya. Konsep Agency Theory adalah hubungan atau kontrak antara principal dan agen. Principal memperkerjakan agen untuk melakukan tugas dalam rangka memenuhi kepentingan principal.

\section{Teori Regulasi}

Teori regulasi menurut Stigler (1971) adalah aktivitas seputar peraturan menggambarkan persaudaraan diantara kekuatan politik dari kelompok berkepentingan sebagai sisi permintaan dan legislatif sebagai supply. Teori ini berpendapat bahwa dibutuhkan aturan-aturan atau ketentuan dalam akuntansi. Pemerintah dibutuhkan peranannya untuk mengatur ketentuan-ketentuan terhadap apa yang harus dilakukan perusahaan untuk menentukan informasi. Ketentuan diperlukan agar semuanya baik pemakai maupun penyaji mendapatkan informasi yang sama dan seimbang. Dalam teori ini kewenangan pusat termasuk badan pengawas regulator diasumsikan memiliki kepentingan terbaik dihati masyarakat. Pemerintah di banyak negara telah membentuk badan pembuat peraturan yang bekerja secara independen dan berusaha untuk menghasilkan standar akuntansi dengan kualitas tinggi yang akan memenuhi kebutuhan para pengguna laporan keuangan dalam membuat suatu keputusan. Beberapa pihak yang berperan aktif dalam laporan keuangan adalah pembuat laporan keuangan dan auditor eksternal serta pembuat peraturan seperti pemerintah dan departemennya.

\section{Perbedaan Pengakuan Nilai Aset Sebelum dan Sesudah Penerapan Sistem Akuntansi Berbasis Akrual}

Dengan berubahnya Peraturan Pemerintah Nomor 24 Tahun 2005 tetang Standar Akuntansi Pemerintah Berbasis Kas atau Kas Menuju Akrual menjadi Peraturan Pemerintah Nomor 71 Tahun 2011 tentang Standar Akuntansi Pemerintah Berbasis Akrual maka secara langsung berubah pula pencatatan dan penyajian dalam penyusunan laporan keuangan pemerintah. Dalam PP 24 tahun 2005 salah satunya adalah mengatur tentang penyajian Neraca yang sebelumnya menggunakan kas basis menjadi kas menuju akrual. Namun, berdasarkan hasil pengamatan penulis pada kenyatannya masih banyak laporan keuangan pemerintah yang belum sepenuhnya menggunakan system pencatatan secara akrual basis pada penyajian neraca. Berdasarkan hasil wawancara penulis dengan beberapa praktisi pada Badan Keuangan dan Aset Daerah, mereka menyatakan bahwa hal tersebut dikarenakan adanya beberapa hal. Seperti misalnya dalam PP No. 24 Tahun 2005 belum mengatur tentang pencatatan beban penyisihan piutang tak tertagih dan penyisihan piutang, begitu pula dengan beban penyusutan aktiva tetap dan akumulai penyusutan aktiva tetap. Pada sisi lain IAI sebagai team penerbit Buletin Teknis (Bultek) juga belum menerbitkan Buletin teknis tentang beban penyisihan piutang tak tertagih dan penyisihan piutang, begitu pula dengan beban penyusutan aktiva tetap dan akumulai penyusutan aktiva tetap.Oleh karena itu untuk mencegah terjadinya kesalahan dalam pencatatan maka pemerintah daerah belum sepenuhnya melaksanakan perhitungan penyisihan piutang dan penyusutan aktiva tetap pada laporang neraca.

Hal yang sama pula terjadi untuk amortisasi aset tidak berwujud pada aktiva lainnya. Masih menurut beberapa praktisi pada Badan Keuangan dan Aset Daerah, hal tersebut dikarenakan dalam PP 24 tahun 2005 belum mengatur standar pencatatan dan penyajian Laporan Operasional sebagai sarana menyajikan beban-beban sehingga akun-akun pada neraca disajikan dengan tidak menggambarkan kondisi yang sebenarnya untuk piutang, aset tetap maupun aset tidak berwujud. 
PP 24 tahun 2005 juga belum mengatur standar penyajian persedian sehingga persediaan hanya menyajikan hasil opname akhir tahun tidak menyajikan jumlah konsumi persediaan selama satu tahun anggaran.

Meskipun PP No.71 Tahun 2011 secara tegas mencabut pemberlakuan PP No. 24 Tahyn 2005, namun kenyataannya pemerintah daerah belum melaksanakan PP 71 Tahun 2011 secara penuh. Oleh karena itu diterbitkan Peraturan Menteri Dalam Negeri nomor 64 Tahun 2013 tentang Penerapan Akuntansi Akrual bagi pemerintah daerah. Dalam PP No.64 Tahun 2013 tersebut diantaranya mengatur bahwa penerapan sisten akuntansi pemerintah berbasis akrual penuh dilaksanakan paling lambat lima tahun setelah di terbitkannya PP No. 71 Tahun 2011. Pada sisi lain apabila diperhatikan isi lampiran II PP No.71 Tahun 2011 maka ditemukan kesamaan dengan muatan PP No. 24 tahun 2005 dengan kata lain lampiran II PP No 71 Tahun 2011 merupakan turunan dari muatan PP 24 Tahun 2005.

Berdasarkan hal tersebut pelaksanaan standar akuntansi pemerintah berbasis akrual hakekatnya sudah dilaksanakan sejak tahun 2011 meskipun belum sepenuhnya tetapi dilakukan bertahap dalam rangka menuju akrual penuh sejak tahun 2015. Implementasinya diwujudkan dengan penambahan komponen laporan keuangan yaitu laporan operasional, laporan perubahan saldo anggaran lebih dan laporan perubahan ekuitas dalam unsur laporan keuangan, serta penambahan pada ciri keuangan pemerintah bagi pengendalian tentang penyusutan nilai aset sebagai sumber daya ekonomi karena digunakan dalam kegiatan operasional pemerintahan (PP 71 Tahun 2010 Kerangka Konseptual Paragraf 16) dan pengakuan aset (Paragraf 90) yaitu piutang atau beban dibayar dimuka diakui ketika hak klaim untuk mendapatkan arus kas masuk atau manfaat ekonomi lainnya dari entitas lain telah atau tetap masih terpenuhi, dan nilai klaim tersebut dapat diukur atau diestimasi.

Fenomena perubahan atas Sistem Akuntansi Pemerintah merupakan suatu hal yang menarik untuk dikaji lebih lanjut, karena dengan berubahnya sistem akuntansi berubah pula dalam penyusunan laporan keuangan baik dalam hal pengakuan, penilaian, penyajian dan kebijakan lainnya dan akan mempengaruhi kualitas laporan keuangan itu sendiri yang tergambar dari hasil pemeriksaan oleh BPK RI. Keberadaan aset juga mempengaruhi kelancaran roda penyelenggaraan pemerintahan danpembangunan. Sistem Pengendalian Intern atas pengelolaan aset negara harus dilakukan secara optimal untuk mencegah penyimpangan yang dapat merugikan negara, selain itu menurut Meta (2016)perubahan sistem akuntansi pemerintah juga membawa perbedaan dalam penyajian laporan keuangan.

Menurut Dewi (2012), Untuk pernyajian asset tetap karena IPSAS menggunakan standar akuntansi berbasis akrual maka pendapatan atau biaya yang timbul pada saat transaksi akan diakui pada saat timbulnya hak/kewajiban. Akibatnya maka depresiasi diakui sebagai biaya dan mengurangi nilai asset tetap.

Penelitian yang dilakukan Sandra dan Satriawan (2016) menyatakan bahwa terdapat perbedaan dasar pencatatan berbasis kas dengan dasar pencatatan berbasis akrual. Karena, dasar pencatatan berbasis kas pada aset yang diterima dari pusat diakui sebagai pendapatan dan belanja modal dalam jumlah yang sama dalam laporan realisasi anggaran, sedangkan dasar pencatatan berbasis akrual aset yang diterima dari pusat tersebut diakui sebagai pendapatan operasional, perbedaan pencatatan unsur aset dan ekuitas dana berbasis kas dengan berbasis akrual, unsur kewajiban tidak terdapat perbedaan pencatatan berbasis kas dengan berbasis akrual.

Berdasarkan penjelasan yang telah di paparakan maka hipotesis yang diajukan adalah:

$\mathrm{H}_{1}$ : Terdapat pernuruan nilai aset lancar sesudah penerapansistem akuntansi pemerintah berbasis akrual.

$\mathrm{H}_{2}$ : Terdapat penurunan nilai aset tetap sesudah penerapansistem akuntansi pemerintah berbasis akrual.

$\mathrm{H}_{3}$ : Terdapat penurunan nilai aset lainnya sesudah penerapansistem akuntansi pemerintah berbasis akrual. 


\section{Kualitas Laporan Keuangan Sebelum dan Sesudah Penerapan SAP Berbasis Akrual}

Begitu pentingnya peran pengungkapan dalam laporan keuangan, pemeriksaan laporan keuangan dilakukan oleh pihak yang independen dikarenakan informasi pengungkapan dalam laporan keuangan memiliki konsekuensi ekonomis yang substansial dalam pengambilan keputusan. Selain itu para pengguna laporan keuangan memerlukan pihak yang independen, untuk mendapatkan penjelasan tentang informasi yang disajikan dalam laporan keuangan. Seluruh komponen laporan keuangan pemerintah daerah diatur dalam Standar Akuntansi Pemerintahan yang diatur dalam Peraturan Pemerintah No. 71 tahun 2010. PP No. 71 Tahun 2010 ini diatur bahwa basis akuntansi yang digunakan untuk mengungkapkan LKPD adalah basis akrual. PP ini memperbaharui SAP sebelumnya yaitu PP No. 24 Tahun 2005 yang masih menggunakan basis cash towards accrual namun masih diberi tenggang waktu hingga tahun 2014 untuk mengubah basis akuntansi yang digunakan. Pengungkapan LKPD daerah disajikan dalam Catatan atas Laporan Keuangan yang merincikan bagian-bagian dalam LKPD dan pengungkapanpengungkapan lain yang perlu.

Penerapan Sistem Akuntansi berbasis akrual merupakan salah satu upaya pemerintah dalam mewujudkan transparantasi dan akuntanbilitas pengelolaan keuangan, sehingga dapat lebih teratur kinerjanya. Hal tersebut diharapkan mampu mendorong efisiensi atas kegiatan-kegiatan yang dilakukan dan mendorong terwujudnya good and clean corporate governance, sehingga tujuan pembangunan untuk kemakmuran seluruh rakyat dapat dicapai. Untuk mencapai tujuan tersebut pemerintah dan seluruh pemerintah daerah harus dapat mempertahankan kualitas laporan keuangannya yang tergambar dari opini yang diberikan BPK (Saleh, 2015).

Pencapaian opini atas laporan keuangan di tahun pertama penerapan akuntansi akrual juga menunjukan optimisme pemerintah dan menjadi batu pijakan awal peningkatan kualtias laporan keuangan di masa mendatang (Meta, 2016)

Berdasarkan penjelasan yang telah di paparakn maka hipotesis yang diajukan adalah:

$\mathrm{H}_{4}$ : Kualitas laporan keuangan sesudah penerapan standar akuntansi pemerintah berbasis akrual lebih baik dibanding sebelum akrual.

\section{METODE PENELITIAN Sampel}

Populasi adalah kumpulan dari keseluruhan eleman yang akan ditarik kesimpulan (Cooper dan Schinder, 2006). Populasi penelitian ini adalah seluruh pemerintah di Indonesia.

Sampel adalah elemen sebuah populasi yang akan diambil kesimpulannya dan mencerminkan kondisi populasinya (Cooper dan Schinder, 2006). Sampel dalam penelitian ini adalah pemerintah provinsi, daerah dan kota di Indonesia.

\section{Definisi operasional variable \\ Aset Lancar}

Asetlancar menurut SAP Nomor 71 Tahun 2010 adalah uang kas dan aset-aset lain atau sumber-sumber yang diharapkan akan direalisasi menjadi uang kas atau dijual atau dikonsumsi selama siklus usaha/operasional yang normal atau dalam waktu satu tahun, mana yang lebih lama.

Dalam penelitian ini, asset lancar diukur dengan :

Aset lancar $=$ Jumlah Aset Lancar

\section{Aset Tetap}

Aset tetap menurut SAP Nomor 71 Tahun 2010adalah aset berwujud yang mempunyai masa manfaat lebih dari 12 (dua belas) bulan untuk digunakan dalam kegiatan pemerintah atau dimanfaatkan oleh masyarakat umum. 
Dalam penelitian ini, asset tetap diukur dengan :

Aset Tetap $=$ Jumlah Aset Tetap

\section{Aset Lainnya}

Berdasarkan PMK 219/PMK 05/2013 tenyang kebijakan pemerintah pusat, definisi aset lainnya dan pemendagri nomor 64 tentang standar akuntansi pemerintahan berbasis akrual pada pemerintah daerah, asset lainnya adalah aset pemerintah selain aset lancar, investasi jangka panjang, aset tetap dan cadangan serta piutang jangka panjang.

Dalam penelitian ini, asset lainnya diukur dengan :

Aset Lainnya = Jumlah Aset Lainnya

\section{Kualitas Laporan Keuangan}

Menurut Handayani (2012), kualitas laporan keuangan pemerintah dapat diukur dari opini auditor. Akuntabilitas pemerintah antara lain terlihat dari opini yang diberikan BPK terhadap laporan keuangan yang diperiksa. Semakin baik pengelolaan keuangan yang dilakukan oleh pemerintah, maka akan semakin baik kualitas laporan keuangan. Dengan diperolehnya opini WTP oleh suatu LKKL ataupun LKPD, menunjukkan akuntabilitas semakin baik.

Dalam penelitian ini, kualitas laporan keungan diukur dengan variable dummy. Yaitu 1 untuk laporan keuangan yang memperoleh opini WTP oleh audit dan 0 untuk laporan keuangan yang memperoleh opini selain WTP oleh audit

\section{Metode Analisis Data}

Pengujian hipotesis ini menggunakan uji statistik parametric dan non-parametric. Berdasarkan parameternya statistic dibagi menjadi dua, yakni parametric dan non-parametric. Statistik parametric adalah statistik yang mempertimbangkan jenis sebaran atau distribusi data, yaitu apakah data menyebar secara normal atau tidak. Dengan kata lain, data yang akan dianalisis menggunakan statistic parametric harus memenuhi asumsi normalitas. Sementara itu, statistik non-parametric adalah statistik yang modelnya tidak menetapkan syarat-syarat mengenai parameter populasi terhadap sampel penelitian. Hipotesis diuji dengan menggunakan paired sample t-test dan wilcoxon signed rank test. Paired sample t-test digunakan untuk menguji ada tidaknya perbedaan dua rata-rata populasi yang datanya berbentuk interval dan rasio serta berdistribusi normal. Sementara itu, Wilcoxon signed rank test digunakan untuk mengevaluasi perlakuan (treatment) tertentu pada dua pengamatan,antara sebelum dan sesudah adanya perlakuan tertentu. Dalam penelitian ini Paired sample t-test dan wilcoxon signed rank test digunakan untuk menguji masing-masing sub variable penelitian.

\section{ANALISIS DAN PEMBAHASAN}

Dalam penelitian ini yang menjadi objek penelitian adalah pemerintah provinsi, daerah dan kota di Indonesia. Jumlah seluruh pemerintahan daerah provinsi, daerah dan kota di Indonesia adalah sebanyak 542 di tahun 2015. Data berupa Ikhtisar Hasil Pemeriksaan LKPD di tahun 2014 dan 2015 yang telah selesai diperiksa oleh BPK.Berdasarkan kriteria pemilihan sampel yang telah ditetapkan, diperoleh jumlah sampel sebanyak 430 untuk sebelum penetapan sistem akuntansi berbasis akrual dan 430 untuk setelah penetapan sistem akuntansi berbasis akrual. Sampel dalam penelitian ini dipilih mengggunakan teknik purpossive sampling atau berdasarkan kriteria tertentu yaitu :

\section{Tabel 1. Sampel Penelitian}




\begin{tabular}{|l|l|l|}
\hline No & Keterangan & Jumlah \\
\hline 1. & $\begin{array}{l}\text { LKPD tahun anggaran 2014-2015 yang telah } \\
\text { diserahkan dan telah selesai diperiksa oleh BPK }\end{array}$ & 542 \\
\hline 2 & $\begin{array}{l}\text { LKPD tahunanggaran yang } \\
\text { telahmenerapkansystemakrual }\end{array}$ & $(104)$ \\
\hline 3. & Tidak memperoleh Opini dari BPK & 430 \\
\hline 4. & Jumlah sampel & \\
\hline
\end{tabular}

Sumber : Data Sekunder yang telahdiolah

Berdasarkan hajil pengujian deskriptif statistik diperoleh hasil sebagai berikut:

1. Mean aset lancar sebelum penerapan sistem akuntansi berbasis akrual sebesar Rp 1.339.558.226.128,46 dan sesudah penerapan sistem akuntansi berbasis akrual sebesar Rp1.193.261.275.735,65. Dengan demikian terlihat adanya penurunan nilai aset lancar sebesar Rp 146.296.950.393 setelah penerapan sistem akuntansi berbasis akrual;

2. Mean aset tetap sebelum penerapan sistem akuntansi berbasis akrual sebesar Rp 4.901.290.902.796,35 dan sesudah penerapan sistem akuntansi berbasis akrual sebesar Rp 4.254.634.483.124,23. Dengan demikian terlihat adanya penurunan nilai aset tetap sebesar $\mathrm{Rp}$ 646.656.419.672 setelah penerapan sistem akuntansi berbasis akrual; dan

3. Nilai minimum aset lainnya menunjukan sesuatu yang berbeda dibanding aset lancar dan aset tetap terlihat dengan nilai 0 (nol). Nilai nol disebabkan ada beberapa sempel pada daerah (kabupaten) yang tidak memiliki nilai aset lainnya. Adapun daerah (kabupaten) yang tidak memiliki nilai aset lainnya antara lain: Kab. Buton Selatan, Kab. Buton Tengah, Kab. Kolaka Timur, Kab. Konawe Kepulauan, Kab. Muna Barat, Kab. Kepulauan Sula, Kab. Membramo Tengah, Kab. Puncak, Kab. Manokwari Selatan dan Kab. Pegunungan Arfak. Hal itu dikarenakan daerah (kabupaten) tersebut merupakan daerah-daerah otonomi baru (DOB) dengan kurun waktu tahun 2012-2014. Selanjutnya, nilaimean aset lainnya sebelum penerapan sistem akuntansi berbasis akrual sebesar $\quad \mathrm{Rp}$ 245.266.517.564,45 dan sesudah penerapan sistem akuntansi berbasis akrual sebesar Rp 243.892.960.357,236. Dengan demikian terdapat penurunan nilai aset lainnya sebesar Rp. 1.373.557.207 setelah penerapan sistemakuntansia berbasis akrual.

4. Selanjunyanilai meanuntuk Opini BPK sebelum penerapan sistem akuntansi berbasis akrual sebesar 0,46 dan sesudah penerapan sistem akuntansi berbasis akrual sebesar 0,59.Dengan demikian terlihat bahwa nilai Opini BPK sesudah penerapan sistem akuntansi berbasis akrual lebih tinggi dibandingkan dengan nilai Opini BPK sebelum penerapan sistem akuntansi berbasis akrual.

Berdasarkan uji asumsi klasik yang telah dilakukan, diperoleh data pada penelitian ini berdistribusi tidak normal. Dikarenakan data yang berdistribusi tidak normal, maka uji yang dilakukan untuk pengujian hipotesis menggunakan Wilcoxon signed rank test. Hal tersebut dikarenakan pengujian dengan statistik non-parametric adalah statistik yang modelnya tidak menetapkan syaratsyarat mengenai parameter populasi terhadap sampel penelitian.

Dari hasil uji Wilcoxon signed rank test, diperolehnilai Z-hitung lebih besar disbanding Z-tabel, serta $P$ value lebih kecil dibanding alpha untuk setiap pengujian variabel. Dengan demikian, seluruh hipotesis yang diajukan dalam penelitian ini didukung.

\section{Penurunan Nilai Aset Lancar Sesudah Penerapan Sistem Akuntansi Berbasis Akrual}

Hipotesis 1 menunujukan adanya penurunan signifikan nilai aset lancar dengan nilai lebih kecil setelah penerapan sistem akuntansi berbasis akrual, dibandingkan sebelum penerapan sistem akuntansi berbasis akrual. Penurunan nilai aset lancar tersebut dapat diketahui dengan mengamati nilai mean 
pada tabel 4.2 dan 4.3. Nilai mean untuk aset lancar sebelum penerapan sistemakuntansi berbasis akrual sebesar Rp.1.339.558.226.128,46menjadi Rp.1.193.261.275.735,65.Terdapat penurunanmeanyang cukup signifikan sebesar Rp. 146.296.950.393 hal tersebut dikarenakan adanya penambahan penyajian akun dalam penyajian neraca yaitu penyisihan piutang hal tersebut dikarenakan pada tahun 2014 pencatatan beban penyisihan piutang tak tertagih dan penyisihan piutang belum diatur dalam peraturan pemerintah nomor 24 tahun 2005 dan pada buletin teknis nomor 06 telah diganti dengan buletin teknis nomor 16 Bab VII yang mengatur tentang Penghapustagihan Piutang. Atas penambahan akun dalam penyajian laporan keuangan sangat mempengaruhi nilai (saldo) akhir neraca yang disajikan. akun tersebut menyebabkan nilai asset lancar menjadi lebih kecil dibanding sebelumnya dalam penyajian asset lancar pada neraca

Sandra dan Satriawan (2016) menyatakan bahwa terdapat perbedaan dasar pencatatan berbasis kas dengan dasar pencatatan berbasis akrual. Karena, dasar pencatatan berbasis kas pada aset yang diterima dari pusat ( dropping) diakui sebagai pendapatan dan belanja modal dalam jumlah yang sama dalam laporan realisasi anggaran, sedangkan dasar pencatatan berbasis akrual aset yang diterima dari pusat tersebut diakui sebagai pendapatan operasional. Pada saat pengunaan system kas menuju akrual, aset yang diterima dari pusat diakui sebagai dua akun, tetapi ketika penerapan system akrual aset tersebut hanya diakui sebagai satu akun saja dalam pengakuannya sehingga mengakibatkan adanya perbedaan dasar pencatatan yang dapat mempengaruhi nilainya dikemudian hari.

\section{Penurunan Nilai Aset Tetap Sesudah Penerapan Sistem Akuntansi Berbasis Akrual}

Hasil hipotesis 2 dalam penelitian ini menunjukan terdapatnya penurunan signifikan nilai aset tetap sesudah penerapan sistem akuntansi berbasis akrual. Nilai aset tetap mengalami penurunan setelah penerapan sistem akuntansi berbasis akrual. Hal tersebut ditunjukan dengan nilai meanpada tabel 4.2 dan 4.3 statistik deksriptif. Nilai meanaset tetap mengalami penurunan sebesar Rp.646.656.419.672 dimana nilai aset tetap sebelum penerapan sistem akuntansi berbasis akrual sebesar Rp. 4.901.290.902.796,35 dan sesudah penerapan sistem akuntansi berbasis akrual Rp.4.254.634.483.124,23.

PSAP 07 Paragraf 20 menyatakan bahwa: Aset tetap dinilai dengan biaya perolehan. Apabila penilaian aset tetap dengan menggunakan biaya perolehan tidak memungkinkan maka nilai aset tetap didasarkan pada nilai wajar pada saat perolehan.PSAP 07 Paragraf 20 menyatakan bahwa: Aset tetap dinilai dengan biaya perolehan. Apabila penilaian aset tetap dengan menggunakan biaya perolehan tidak memungkinkan maka nilai aset tetap didasarkan pada nilai wajar pada saat perolehan.

Sesuai dengan PSAP 07 Paragraf 52, aset tetap disajikan berdasarkan biaya perolehan aset tetap tersebut dikurangi akumulasi penyusutan. Dengan demikian, Jalan, Irigasi, dan Jaringan disajikan berdasarkan biaya perolehan dikurangi dengan akumulasi penyusutan. Metode penyusutan atas jalan, irigasi, dan jaringan diatur dalam Buletin Teknis Nomor 05 yang telah diganti dengan buletin teknis nomor 18 tentang Akuntansi Penyusutan. Dalam PP 24 aset tetap disajikan berdasarkan biaya perolehan, tetapi belum dikurangi dengan akumulasi penyusutan. Sedangkan pada PP 70 aset tetap disajikan berdasarkan biaya perolehan aset tetap tersebut dikurangi akumulasi penyusutan.

Penelitian Alimah dan Mufarrohah (2017), menunjukan adanya penurunan nilai aset setelah penerapan sistem akrual basis. Adanya penurunan tersebut dikarenakan adanya penerapan akumulasi penyusutan terhadap aset tetap.Sesuai dengan PSAP 07 Paragraf 52, aset tetap disajikan berdasarkan biaya perolehan aset tetap tersebut dikurangi akumulasi penyusutan.

\section{Penurunan Nilai Aset Lainnya SesudahPenerapanSistemAkuntansi Berbasis Akrual}

Hipotesis 3 didukung, pada uji wilcoxon menunujukan adanya penurunan signifikan nilaiaset lainnya, yang mana nilai aset lainnya setelah penerapan sistem akuntansi berbasis akrual lebih 
kecildibandingkan sebelum penerapan sistem akuntansi berbasis akrual. Penurunan nilai aset lainnya sebesar Rp.268.689.188.180 dapat diketahui dengan mengamati nilai mean pada tabel 4.2 dan 4.3 yaitu tabel statistik deskriptif. Nilai meanuntuk aset lainnya sebelum penerapan sistem akrual sebesar Rp.245.266.517.564,45.kemudian menurun menjadi Rp243.892.960.357,236. Hal tersebut dikarenakan adanya perbedaan pengakuan sistem akuntansi akrual basis dan kas basis. Terlihat dengan adanya penambahan akun-akun pada penyajian laporan keuangan (neraca) setelah penerapan sistem akrual seperti akun penyisihan terhadap tagihan tuntutan ganti rugi, amortisasi aset tidak berwujud dan adanya akumulasi penyusutan untuk aktiva lainnya atas penjelasan tersebut dapat dilihat pada buletin teknis nomor 11 yang telah diganti dengan buletin teknis nomor 17 tentang Akuntansi Aset Tak Berwujud. Adanya penyisihan dan pencadangan terhadap suatu akun, maka dapat mengurangi nilai pada akun itu sendiri sehingga sangat mempengaruhi nilai (saldo) akhir neraca yang disajikan.

Menurut PP 71 Tahun 2011, basis akuntansi yang digunakan dalam laporan keuangan pemerintah adalah basis kas untuk pengakuan pendapatan, belanja, dan pembiayaan dalam Laporan Realisasi Anggaran dan basis akrual untuk pengakuan aset, kewajiban, dan ekuitas dalam Neraca. Basis akrual untuk Neraca berarti bahwa aset, kewajiban, dan ekuitas dana diakui dan dicatat pada saat terjadinya transaksi, atau pada saat kejadian atau kondisi lingkungan berpengaruh pada keuangan pemerintah, tanpa memperhatikan saat kas atau setara kas diterima atau dibayar. Berbeda dengan sistem kas yang mencatat transaksi setelah uang atau kas sudah benar-benar dikeluarkan. LKPD tahun 2015 harus menggunakan SAP berbasis akrual sesuai Peraturan Pemerintah Nomor 71 Tahun 2010, yaitu SAP yang mengakui pendapatan, beban, aset, hutang, dan ekuitas dalam pelaporan finansial berdasarkan basis akrual, serta mengakui pendapatan, belanja, dan pembiayaan dalam pelaporan pelaksanaan anggaran berdasarkan basis yang ditetapkan dalam AnggaranPendapatan dan Belanja Negara/Anggaran Pendapatan dan Belanja Daerah. Menghadapi tuntutan aturan tersebut, dalam pencatatan aset pada LKPD, maka pemerintah daerah wajib mencantumkan nilai sewajarnya dari suatu aset.

Pada penelitian ini, seluruh nilai asset mengalami penurunan dan seluruh hipotesis diterima. Hal tersebut dapat dikarenakan, setelah pemerintah mengeluarkan PP 71 tahun 2010, yang merupakan penegasan kembali penggunaan akrual basis dalam system penyajian laporan keuangan serta telah adanya bulletin teknis yang memberikan contoh pencatatan dalam penerapan sistema akrual yang lebih terperinci. Sehingga, para staff keperintahan dapat lebih memahami serta mematuhui peraturan terhadap penyajian laporan keuangan, terutama penyajian neraca dalam bentuk akrual basis yang seutuhnya.

\section{Kualitas Laporan Keuangan Sesudah PenerapanSistem Akuntansi Berbasis Akrual Lebih Baik Dibanding Sebelum Akrual}

Hipotesis 4 dalam penelitian ini didukung, yaitu terdapat perbedaan kulitas laporan keuangan sebelum dan setelah penerapan sistem akrual dimana kualitas laporan keuangan setelah penerapan sistem akrual lebih baik disbanding sebelum penerapan sistem akrual.hal ini diketahui dari adanya peningkatan opini WTP yang diterima oleh pemerintah daerah sebesar 58,8\% yang sebelumnya hanya sekitar 46,3\%, atau telah terjadi peningkatan opini WTP sebesar $12,5 \%$.

Dampak positif dari penerapan sistem akuntansi berbasis akrual juga telah banyak diakui oleh para peneliti. Nirmala, etal (2014) menyebutkan bahwa perubahan basis akuntansi sektor publik dari basis kas menuju akrual menjadi basis akrual disebabkan oleh kelemahan basis kas dalam menghasilkan informasi yang cukup untuk pengambilan keputusan (misalnya informasi tentang utang dan piutang). Informasi yang dihasilkan basis akrual lebih tepat untuk menggambarkan biaya operasi yang sebenarnya, dapat menghasilkan informasi yang dapat diandalkan dalam informasi aset dan kewajiban dan dapat menghasilkan informasi keuangan yang komprehensif tentang pemerintah. Dari 
penjelasan di atas dapat disimpulkan bahwa dengan menggunakan basis akrual, maka pemerintah daerah dapat menghasilkan keputusan internal yang tepat karena pemerintah daerah memperoleh informasi yang lebih baik dan komprehensif terkait dengan sumber daya ekonominya.

Bagi pemerintah daerah menjadi suatu keharusan untuk menyusun laporan keuangan yang berkualitas. Kualitas laporan keuangan pemerintah daerah mencerminkan tertib pengelolaan keuangan pemerintah daerah, yang mencakup tertib administrasi dan taat asas. Indikator bahwa laporan keuangan pemerintah daerah sudah berkualitas yaitu opini WTP atau WTP DPP yang diberikan Badan Pemeriksa Keuangan terhadap LKPD. Pemerintah daerah sebagai entitas pelaporan wajib menyampaikan laporan keuangannya. Laporan keuangan diharapkan dapat memberikan informasi keuangan kepada berbagai kelompok kepentingan yang ingin mengetahui entitas secara lebih dalam, di mana adanya perbedaan karakteristik antar entitas yang akan memberikan perbedaan nilai dalam laporan keuangan masing-masing entitas.

Kepatuhan dalam penyajian laporan keuangan kepada publik di Indonesia telah diatur dalam Peraturan Pemerintah Nomor 71 Tahun 2010. Sebelum laporan keuangan pemerintah daerah diterbitkan, laporan tersebut harus diaudit oleh Badan Pemeriksa Keuangan untuk menilai kewajarannya dan diberikan opini atas laporan keuangan tersebut. Dengan demikian, teori entitas dan teori regulasi yang diajukan terdukung, dimana menjadi sebuah keharusan dan kewajiban bagi pemerintah daerah selaku entitas pelaporan untuk menerapkan Peraturan Pemerintah Nomor 71 Tahun 2010 dalam penyusunan Laporan Keuangan Pemerintah Daerah sebagai dampak dari regulasi peraturan pemerintah.

\section{E. SIMPULAN DAN SARAN \\ Simpulan}

Berdasarkan hasil penelitian dan pembahasan pada bab sebelumnya, maka dapat ditarik simpulan dalam penelitian ini sebagai berikut:

1. Hipotesis 1 didukung. Terdapat penurunan aset lancar sesudah penerapan sistem akuntansi berbasis akrual. Nilai aset lancar setelah penerapan sistem akuntansi berbasis akrual lebih kecil dibanding sebelumnya. Hal tersebut dikarenakan adanya beberapa penambahan akun untuk aset lancar dalam penyajian laporan keuangan antaralain penyisihan piutang dan perubahan atas pencatatan saldo akhir persediaan.

2. Hipotesis 2 didukung. Terdapat penurunan signifikan aset tetap sesudah penerapan sistem akuntansi berbasis akrual. Nilai aset tetap setelah penerapan sistem akuntansi berbasis akrual lebih kecil dibanding sebelumnya. Hal tersebut disebabkan diberlakukannya akumulasi penyusutn aset tetap pada neraca laporan keuangan, sesuai dengan PSAP 07 Paragraf 52, aset tetap setelah penerapan sistem akrual disajikan berdasarkan biaya perolehan aset tetap tersebut dikurangi akumulasi penyusutan.

3. Hipotesis 3 didukung. Terdapat penurunan signifikan aset lainnya sesudah penerapan sistem akuntansi berbasis akrual. Nilai aset lainnya setelah penerapan sistem akuntansi berbasis akrual lebih kecil dibanding sebelumnya. Hal tersebut dikarenakan terdapat beberapa penambahan akun setelah penerapan sistem akrual yang dapat mempengaruhi nilai aset lainnya seperti akun penyisihan terhadap tagihan tuntutanganti rugi, amortisasi aset tidak berwujud dan adanya akumulasi penyusutan untuk aktiva lainnya.

4. Hipotesis 4 didukung. Terdapat kenaikan signifikan rata-rata opini BPK sesudah penerapan sistem akuntansi berbasis akrual. Informasi yang dihasilkan basis akrual lebih tepat untuk menggambarkan biaya operasi yang sebenarnya, dapat menghasilkan informasi yang dapat diandalkan dalam informasi aset dan kewajiban dan dapat menghasilkan informasi keuangan yang komprehensif tentang pemerintah. 


\section{Keterbatasan}

Penelitian ini memiliki beberapa keterbatasan. Pertama, periode sampel penelitian dimulai tahun 2014 dan 2015, dimana tahun 2015 merupakan tahun pertama penerapan basis akrual pada penyusunan laporan keuangan pemerintah daerah sehingga periode pengamatan masih sangat pendek antara batas penerapan System akrual dengan data yang diteliti. Kedua, peneleliti tidak memisahkan pengujian terhadap masing-masing daerah, provinsi dan kota sehingga hasil penelitian ini menjadi lebih general dan tidak spesifik untuk mengetahui dampak penerapan sistem akrual pada sektor pemerintah.

\section{Saran}

Atas keterbatasan tersebut, untuk penelitian selanjutnya disarankan agar menambah tahun pengamatan, terlebih lagi tahun setelah penerapan akrual. Selain itu, peneliti selanjutnya dapat membuat analisis tambahan terhadap masing-masig wilayah, seperti daerah, kota dan provisi serta penambahan variabel-variabel lain yang yang memiliki pengaruh terhadap penerapan basis akrual, misalnya karakteristik pemerintah daerah, umur pemerintah daerah dan sebagainya. Selain itu juga dapat dilakukan penelitian menggunakan data primer terhadap penerapan basis akrual dalam penyusunan laporan keuangan pemerintah daerah.

Dalam mengimplementasikan SAP Akrual terdapat beberapa tantangan yang memerlukan perhatian bagi seluruh pihak yang terkait agar implementasinya dapat berjalan dengan baik dan dapat mencapai tujuan serta manfaat yang diharapkan. Oleh karena itu, diperlukan langkah-langkah yang penuh dengan kehati-hatian dalam menerapkan basis akrual, komitmen politik yang tinggi dari pengambil kebijakan dan persiapan yang matang agar proses perubahan tersebut dapat berjalan sesuai dengan harapan untuk mewujudkan pengelolaan keuangan Negara yang akuntabel.

\section{REFERENSI}

Alimah, Binti Muck danMufarrohah. 2017. AnalisisPenilaianTetapPemerintah Daerah KabupatenBlitarPeriode 2014 dan 2015. Seminar Nasional dan Call For Peper,FEBUnikama

Andrew, Anthony dan Pitt, Michael. 2006.Property Depreciation in Government, Journal of property investment and finance. Vol 24 no. 3

Beechy, T.H. 2007. Does Accrual Accounting Enhance Accountability. The Inovation Journal: The Public Sector Inovation Journal, Volume 12 Nomor 1 hal 1-18.

Buletin Teknis No. 05 tentang Akuntansi Penyusutan, Komite Standar Akuntansi Pemerintahan

Buletin Teknis No. 09 tentang Akuntansi Aset Tetap, Komite Standar Akuntansi Pemerintahan

Chartered Institute of Public Finance and Accountancy. 2002.The role that depreciation could play in local government finance.

Cooper, D.R. dan Schindler, P.S. 2014. Business Reasearch Methods. New York: McGraw-Hill.

Damayanti, RA. 2013. AkuntansiAkrualdanPenerapannya di SektorPublik: Sebuah Agenda Pembaharuan. Modul AkuntansiPemerintahBerbasisAkrual. STAR-BPKP. Jakarta.

Darsono Ashari. 2005.Pedoman Praktis Memahami Laporan Keuangan. Yogyakarta

Halim, A. danSyam, M. 2011. AkuntansiKeuanganDaerah.Jakarta: SalembaEmpat

Hanafi, Mamduh M dan Abdul Halim. 2007.Analisis Laporan Keuangan. UPPSTIM YKPN. Yogyakarta

Handayani, Desi. 2012. Good Governance danKualitasLaporanKeuanganPemerintah. 
Herwiyanti, Elinda. et al. 2017. AnalisisImplementasiAkuntansiBerbasisAkrualpada

InspektoratJenderal Kementerian Keuangan. JurnalAkuntansidanKeuangan, Vol. 19, No. 1. ISSN 2338-8137 online

Indonesia, Undang-Undang No. 17 tahun 2003 Tentang Keuangan Negara Undang-Undang No. 1 tahun 2004 tentang Perbendaharaan Negara

Jensen, Michael C. dan W.H. Meckling. 1976. Theory of The Firm: Managerial

Behavior, Agency Cost and Ownership Structure. www.ssrn.com

Kiesso. 2011. Intermediate Accounting. volume 1. IFRS Edition.

Meta,

Mauritz.

2016.

TransparansidanAkuntabilitasPengelolaanKeuanganPemerintahMelaluiLaporanKeuanganPem erintah Pusat. Treasury Indonesia: hal 14-19.

Muchsini, B. 2010. PengaruhAdopsiAkuntansiBerbasisAkrualTerhadapAkuntabilitasKeuangan Daerah se Jawa-Bali. Tesis Master. UniversitasSebelasMaret, Semarang.

Mulyadi. 2009.Teori Akuntansi Suatu PengantarEdisi Pertama. Prenada Media Group. Jakarta

Mulyadi. 2008. Sistem Akuntansi. Jakarta: Salemba Empat

Munawir. 2006. Analisis Laporan Keuangan. Cetakan Ketigabelas. LIBERTY. Jakarta.

Nasi Greta danSteccolini. 2008. Implementation of Accounting Reform. Public Management Review.Vol. 10 Issue 2.

Peraturan Pemerintah Nomor 71 Tahun 2010 Tentang Standar Akuntansi Pemerintahan. 2010. Jakarta: Sekretariat Negara Republik Indonesia

Peraturan Pemerintah Nomor 24 Tahun 2005 Tentang Standar Akuntansi Pemerintahan. 2005. Jakarta: Sekretariat Negara Republik Indonesia

Purwanugraha, Heribertus Andre. Mahsun, Moh.Sulistyowati, danFirma. 2011, AkuntansiSektorPublik, edisiketiga, BPFE, Yogyakarta.

Rahardjo, Budi. 2005. LaporanKeuangan Perusahaan, serimembaca, memahami, menganalisis, CetakanPertama: Gajah Mada, Yogyakarta.

Renyowijoyo, Muindro. 2010. AkuntansiSektorPublikOrganisasi Non Laba, EdisiKedua, PenerbitMitraWacana Media, Yogjakarta

Ross, A Stephen. 1973. The Economic Theory of Agency: The Pricipal's Problem. American Economics Review 63: 134-139.

Sandra, KamelyadanSatriawan, Bambang. 2016. Analisis Studi Komparatif Dasar Pencatatan Berbasis Kas dengan Berbasis Akrual Terhadap Keakuratan Informasi Laporan Keuangan Pada Kantor Kesehatan Pelabuhan Kelas I. Zona Akuntansi. ISSN 2087-7315

Scott, W.R. 2009. Financial Accounting Theory. Fifth Edition. Canada Prentice Hall 
Sefiana, Eka. 2009. PengaruhPenerapan Corporate Governance terhadapManajemenLabapada Perusahaan Perbankan yang Telah Go Publik di BEI.JurnalEkonomiBisnisdanAkuntansi Ventura 12(3):211-222.

Simanjuntak, Payaman J. 2005. ManajemendanEvaluasiKinerja. Jakarta: FE UI.

Stigler, G. 1971. The Theory of Economic Regulation. Bell Journal of Economics and Management Science 3. Chicago: Rand Corporation.

Van der Hoek, Peter M. 2005. Accrual-Based Budgeting and Accounting in the Public Sector: The Dutch Experience. Erasmus University Rotterdam. MPRA Paper No. 5906, Posted 29.

Warsono,Sony., Amalia,Fitri.,danRahajeng, Dian Kartika. 2009. Corporate Governance Concept and Model: Preserving True Organisation Welfare.Center for Good Corporate Governance. Yogyakarta

http://suhaylazhafira.bolgspot.com/2014/01/makalah-sap-cash-basis-dan-akrual basis.html?m=1

https://www.djkn.kemenkeu.go.id/artikel/pencatatan-bmn-dalam-akuntansi berbasis-akrual-sapoleh-yasser-a-usman-semm

\section{LAMPIRAN}

\section{Descriptive Statistics}

\begin{tabular}{|l|l|l|l|l|l|}
\hline & $\mathrm{N}$ & Minimum & Maximum & Mean & Std. Deviation \\
\hline AsetLancarSe & 43 & 183128550,0 & 14872136514127,0 & 1339558226128,46 & 17173805732181,3 \\
$\mathrm{~b}$ & 0 & 0 & 0 & 00 & 000 \\
AsetLancarSS & 43 & 1046455330, & 17450490675026,0 & 1193261275735,65 & 13780684577138,9 \\
$\mathrm{D}$ & 0 & 57 & 0 & 00 & 000 \\
AsetTetapSeb & 43 & 3869112000, & 341982544524372, & 4901290902796,35 & 24233398291332,5 \\
& 0 & 00 & 00 & 00 & 000 \\
AsetTetapSSd & 43 & 3316979756, & 334403041973049, & 4254634483124,23 & 22331885778922,3 \\
& 0 & 09 & 00 & 00 & 000 \\
AsetLainnyaS & 43 & 0,00 & 51430409936269,0 & 245266517564,450 & 2508707743714,62 \\
eb & 0 & & 0 & 0 & 00 \\
AsetLainnyaS & 43 & 0,00 & 45653550146654,0 & 243892960357,236 & 2240018555534,75 \\
Sd & 0 & & 0 & 0 & 00 \\
Valid & 43 & & & & \\
(listwise) & 0 & & & & \\
\hline
\end{tabular}


Descriptive Statistics

\begin{tabular}{|l|l|l|}
\hline & $\begin{array}{l}\text { opini_sebelu } \\
\text { m_akrual }\end{array}$ & $\begin{array}{l}\text { opini_sesud } \\
\text { ah_akrual }\end{array}$ \\
\hline $\mathrm{N} \quad \begin{array}{l}\text { Valid } \\
\text { Missing }\end{array}$ & 430 & 430 \\
Mean & 0 & 0 \\
Median & .46 & .59 \\
Mode & .00 & 1.00 \\
Std. Deviation & 0 & 1 \\
Minimum & 0 & .493 \\
Maximum & 1 & 0 \\
\hline
\end{tabular}

\section{Opini_sebelum_akrual}

\begin{tabular}{|c|c|c|c|c|c|}
\hline & & Frequency & Percent & Valid Percent & $\begin{array}{l}\text { Cumulative } \\
\text { Percent }\end{array}$ \\
\hline \multirow[t]{3}{*}{ Valid } & 0 & 230 & 53.7 & 53.7 & 53.7 \\
\hline & 1 & 200 & 46.3 & 46.3 & 100.0 \\
\hline & Total & 430 & 100.0 & 100.0 & \\
\hline
\end{tabular}

\section{Opini_sesudah_akrual}

\begin{tabular}{|ll|l|l|l|l|}
\hline & & & & \\
& Frequency & Percent & Valid Percent & $\begin{array}{l}\text { Cumulative } \\
\text { Percent }\end{array}$ \\
\hline Valid & 0 & 177 & 41.2 & 41.2 & 41.2 \\
& 1 & 253 & 58.8 & 58.8 & 100.0 \\
& Total & 430 & 100.0 & 100.0 & \\
\hline
\end{tabular}

\section{One-Sample Kolmogorov-Smirnov Test}

\begin{tabular}{|lr|l|l|}
\hline & & AsetLancarSeb & AsetLancarSSD \\
\hline $\mathrm{N}$ & & 430 & 430 \\
Normal Parameters ${ }^{\mathrm{a}, \mathrm{b}}$ & Mean & $7.18 \mathrm{E} 12$ & $1.57 \mathrm{E} 13$ \\
& \multicolumn{1}{|c|}{ Std. Deviation } & $2.618 \mathrm{E} 13$ & $1.759 \mathrm{E} 14$ \\
Most $\quad$ Extreme Absolute & .392 & .464 \\
Differences & Positive & .336 & .417 \\
& Negative & -.392 & -.464 \\
Kolmogorov-Smirnov Z & 8.127 & 9.631 \\
Asymp. Sig. (2-tailed) & .000 & .000 \\
\hline
\end{tabular}

a. Test distribution is Normal. 
Opini_sesudah_akrual

\begin{tabular}{|l|l|l|l|l|}
\hline & & & & $\begin{array}{l}\text { Cumulative } \\
\text { Percent }\end{array}$ \\
\hline Valid 0 & 177 & 41.2 & 41.2 & 41.2 \\
1 & 253 & 58.8 & 58.8 & 100.0
\end{tabular}

b. Calculated from data.

\section{One-Sample Kolmogorov-Smirnov Test}

\begin{tabular}{|c|c|c|c|}
\hline & & AsetTetapSeb & AsetTetapSSd \\
\hline \multicolumn{2}{|l|}{$\mathrm{N}$} & 430 & 430 \\
\hline \multirow[t]{2}{*}{ Normal Parameters ${ }^{\mathrm{a}, \mathrm{b}}$} & Mean & $5.98 \mathrm{E} 13$ & $5.23 \mathrm{E} 13$ \\
\hline & Std. Deviation & $1.865 \mathrm{E} 14$ & $2.654 \mathrm{E} 14$ \\
\hline \multirow{3}{*}{$\begin{array}{l}\text { Most } \\
\text { Differences }\end{array}$} & Absolute & .383 & .422 \\
\hline & Positive & .383 & .356 \\
\hline & Negative & -.374 & -.422 \\
\hline \multicolumn{2}{|c|}{ Kolmogorov-Smirnov Z } & 7.935 & 8.748 \\
\hline \multicolumn{2}{|l|}{ Asymp. Sig. (2-tailed) } & .000 & .000 \\
\hline
\end{tabular}

a. Test distribution is Normal.

b. Calculated from data.

One-Sample Kolmogorov-Smirnov Test

\begin{tabular}{|c|c|c|c|}
\hline & & $\begin{array}{l}\text { AsetLainnyaSe } \\
\text { b }\end{array}$ & $\begin{array}{l}\text { AsetLainnyaSS } \\
\text { d }\end{array}$ \\
\hline \multicolumn{2}{|l|}{$\mathrm{N}$} & 430 & 430 \\
\hline \multirow[t]{2}{*}{ Normal Parameters ${ }^{\mathrm{a}, \mathrm{b}}$} & Mean & $3.23 \mathrm{E} 12$ & $7.42 \mathrm{E} 14$ \\
\hline & Std. Deviation & $1.193 \mathrm{E} 13$ & $2.997 \mathrm{E} 15$ \\
\hline \multirow{3}{*}{$\begin{array}{l}\text { Most } \\
\text { Differences }\end{array}$} & Absolute & .393 & .498 \\
\hline & Positive & .366 & .498 \\
\hline & Negative & -.393 & -.477 \\
\hline \multicolumn{2}{|l|}{ Kolmogorov-Smirnov Z } & 8.157 & 10.327 \\
\hline \multicolumn{2}{|l|}{ Asymp. Sig. (2-tailed) } & .000 & .000 \\
\hline
\end{tabular}

a. Test distribution is Normal.

b. Calculated from data. 
One-Sample Kolmogorov-Smirnov Test

\begin{tabular}{|c|c|c|c|}
\hline & & $\begin{array}{l}\text { opini_sebelu } \\
\text { m_akrual }\end{array}$ & $\begin{array}{l}\text { opini_sesud } \\
\text { ah_akrual }\end{array}$ \\
\hline \multicolumn{2}{|l|}{$\mathrm{N}$} & 430 & 430 \\
\hline \multirow[t]{2}{*}{ Normal Parameters ${ }^{\mathrm{a}, \mathrm{b}}$} & Mean & .46 & .59 \\
\hline & Std. Deviation & .499 & .493 \\
\hline \multirow{3}{*}{$\begin{array}{l}\text { Most } \\
\text { Differences }\end{array}$} & Absolute & .360 & .386 \\
\hline & Positive & .360 & .296 \\
\hline & Negative & -.322 & -.386 \\
\hline \multicolumn{2}{|l|}{ Kolmogorov-Smirnov Z } & 8.283 & 8.888 \\
\hline \multicolumn{2}{|l|}{ Asymp. Sig. (2-tailed) } & .000 & .000 \\
\hline
\end{tabular}

a. Test distribution is Normal.

b. Calculated from data.

Test Statistics ${ }^{\mathrm{a}}$

\begin{tabular}{|c|c|c|c|}
\hline & $\begin{array}{l}\text { AsetLancarSS } \\
\text { D } \\
\text { AsetLancarSe } \\
\text { b }\end{array}$ & $\begin{array}{l}\text { AsetTetapSS } \\
\text { d } \\
\text { AsetTetapSe } \\
\text { b }\end{array}$ & $\begin{array}{l}\text { AsetLainnyaSS } \\
\text { d } \\
\text { AsetLainnyaSe } \\
\text { b }\end{array}$ \\
\hline $\begin{array}{l}\text { Z } \\
\text { Asymp. Sig. } \\
\text { tailed) }\end{array}$ & $\begin{array}{l}-2,183^{\mathrm{b}} \\
, 029\end{array}$ & $\begin{array}{l}-13,591^{b} \\
, 000\end{array}$ & $\begin{array}{l}-2,908^{\mathrm{c}} \\
, 004\end{array}$ \\
\hline
\end{tabular}
a. Wilcoxon Signed Ranks Test
b. Based on positive ranks.
c. Based on negative ranks. 